\title{
Elements of Javanese Cultures in Ngambu Pancer Folktale from Pacitan
}

\author{
Rizqi Citania Sari ${ }^{1}$, Suyitno ${ }^{2}$, and Nugraheni Eko Wardani ${ }^{3}$ \\ \{rizqicitaniasari@student.uns.ac.id ${ }^{1}$ \} \\ ${ }^{1}$ Postgraduate Student of Universitas Sebelas Maret, Surakarta, Indonesia \\ ${ }^{2,3}$ Faculty of Teacher Training and Education, Universitas Sebelas Maret, Surakarta, \\ Indonesia
}

\begin{abstract}
Ngambu Pancer is one of the folktales from Pacitan Regency that appears as a phenomenal historical heritage. It is renowned due to the mystical belief adhered by the local society after a long time of oral dissemination. The study aimed to describe the Javanese elements in Ngambu Pancer folktale from Pacitan. It used a qualitative method through an ethnographic study that focused on the folktale quotations. The quotations were obtained from the interview transcript with the participants related to the discussion of Ngambu Pancer tradition as the data source. A series of strategies, including interview, observation, documentation, field note, and transcription were deployed as the data collecting technique. Meanwhile, the data analysis used description, analysis, and interpretation. The study adopted triple triangulations, including source, methodological, and theoretical triangulation. The findings revealed three descriptive elements of Javanese cultures in Ngambu Pancer folktale, including (1) knowledge system related to human's curiosity about their living components, (2) social organization that establishes a kinship to comprehend how people could form a society through a social community, and (3) religious system related to the human's belief to the supernatural power above them.
\end{abstract}

Keywords: Javanese Cultural Elements; Folktale; Ngambu Pancer; Pacitan Regency.

\section{INTRODUCTION}

The human and culture are inseparable due to their position as the life components. The human establishes a socio-cultural unity as the foundation of a society. The society then gives birth, creates, grows, and develops their culture of life. The notion is in line with the aim of the study [1], as the culture itself functions as the booster of human's actions. The culture influences human's behavior and paradigm in various social condition, life, traditions, natural states and historical frameworks.

The study aimed to deeply explore the Javanese cultural elements in Ngambu Pancer folktale from Pacitan Regency. The elements were believed of containing a potential cultural preservation values, in addition to provide the knowledge and tourism attraction. The researcher 
adopted a holistic approach to sort the cultural groups, as the analysis utilized the emic data based on the participants' perspective and etic data based on the researcher's perspective as its practical purpose.

Based on the previous studies related to ethnographic exploration and cultural expression related to [2] the relation of coastal cultures with Malin Kundang and Si Tanggang folktale; [3] the traditions of Dawuhan Village in Banyumas as the cultural heritage; [4] the cultural representation found in Dewi Rengganis folktale from Lelakaq Sasak, Lombok; [5] the exploration of cultural elements in Mexico, USA by utilizing folktales to overcome the cultural competition; [6] the cultural heritage of Prigi shore related to Sajen Slametan Njangkar as the symbol of particular message to the Queen of Southern Sea, Kanjeng Ratu Nyi Roro Kidul; [7] the luck, risk, and socio-political implication of the ritual observation to the coastal fishing village; [8] the depiction of the fishermen's local wisdom based on the language tradition and livelihood at the Southern Sea in Kebumen Regency through the ethnolinguistic study; [9] the traditional folktales adopted as the Kazakh cinematography and analyzed specifically through the ethnic values, culture, tradition, and spiritual development; [10] the myth or belief to the Sea Gods based on the Kuroshio Oceanic culture related to maritime tradition and social interaction in Jeju Island, Zhoushan Island, and Ryukyu Island; [11] the meaning and cultural values of Tapis Inuh coastal society in South Lampung.

The study belongs to the interdisciplinary between anthropology and culture, as it utilized an ethnographic approach to analyze the Javanese cultural elements of the historical folktale through the formulation of social behavior, such as tradition, convention, and custom that are produced by the public mentality. The ethnographic approach was adopted to analyze the Javanese cultural elements based on the reference of anthropological theory from [12] and [13], as an attempt to review the society through its culture from the integrated point of view that includes (1) language, (2) knowledge system, (3) social organization, (4) living system and technologies, (5) livelihood system, (6) religious system, and (7) arts. With regards to the notion, Pacitan people in East Java, Indonesia still holds the values of Ngambu Pancer folktale as part of their cultural heritage. The term Ngambu Pancer derives from Javanese language that means Ngabekti Alam Bumi Pancer (devoting self to the nature and the Earth of Pancer shore). The sea is called Pancer due to its location in the eastern region of estuary. Meanwhile, the folktale appeared as the cultural heritage. With regards to the folktale, sesepuh (ancient people) believes that there is a mystical holy region in the forms of Watu Kelir, Watu Mejo, and Watu Goa Bale as the meditation points guarded by the ancestral spirit that resembles a human called Pancer Segoro. There is also a circling pandanus that resembles bush called Pandan Kurung guarded by Raden Mas Joko and Kiai Ageng Tumbu. The Pandan Kurung is believed as a large road to the royal gate of the Queen of Southern Sea, Kanjeng Ratu Nyi Roro Kidul.

The ethnographic study firstly appeared in the form of comparative cultural anthropology led by [14], as it placed the exact sciences as the research model through a traditional scientific approach and first-hand data collecting technique related to the "primitive" culture. The study related to the exploration of a particular group's social interaction that was flexibly observed by the researcher. The notion is also in accordance with [15] stating the study as an interpretation of social behavior, values, faith, and language to obtain cultural comprehension.

\section{METHOD}

The study belongs to a qualitative research through an ethnographic approach. [16] stated that the ethnographic study focused on the social behavior of the target community. The data consisted of the quotations of the folktale that were obtained through the transcript of interview 
with the participants. Ngambu Pancer folktale from Pacitan Regency was taken as the data source. It used the combination of data collecting technique, including interview, observation, documentation, field note, and transcription.

It also referred to three aspects of analysis, including description, analysis, and interpretation. The combination of data analysis was objectively targeted to study the cultural elements of Ngambu Pancer folktale from Pacitan. Meanwhile, the data description included a number of phases, such as establishing, developing, and writing. The first phase placed the researcher to fairly focus on the series of stories to develop them based on the plots and characters, and write the analysis frameworks related to cultural elements. At the second phase, the researcher analyzed a number of data related to (1) knowledge system, (2) social organization, and (3) religious system. The triple analysis was then displayed into tables through a systematical procedure. Meanwhile, the third phase was marked by the researcher's interpretation and conclusion about the discovery. The study used triple triangulation, including (1) source triangulation, (2) methodological triangulation, and (3) theoretical triangulation.

\section{RESULTS AND DISCUSSION}

The findings describe and explain the Javanese cultural elements in Ngambu Pancer folktale from Pacitan Regency through three elements, including: (1) knowledge system, (2) social organization, and (3) religious system.

\subsection{Knowledge System Elements}

The knowledge system elements cover the comprehension of natural conditions and instrument characteristics. The system includes knowledge related to nature, flora and fauna, time, space and numbers, human character and behavior, and human body. The following data are the evidence of the existing knowledge elements in the folktale.

"Membersihkan sampah disekitar atau pesisir pantai, resctoking (penaburan atau penyebaran benih ikan) di sepanjang sungai Grindulu serta beberapa kecamatan, melakukan konservasi Penyu, selain itu juga turut serta menjaga kelestarian alam dengan penghijauan seperti menanam cemara dan bakau di sepanjang pesisir pantai"

'Cleaning the garbage at the coastal area, restocking fish seeds along the Grindulu stream and a number of sub-districts, holding sea turtle conservation, initiating reforestation as an attempt of natural conservation, such as by planting pine trees and mangroves along the shore' (page 4-5)

The quotation contains a knowledge system as part of the cultural elements, as it discusses the activities held by Pacitan people for the natural and sea ecosystem conservation to prevent the extinction.

"Mengkampanyekan sebagai tujuan Stop Illegal Fishing (Hentikan Penangkapan Ikan Secara Ilegal) yang direalisasikan dalam acara lomba Jolo”

'Doing campaign state of 'Stop Illegal Fishing' action that is reflected through Jolo competition' (page 2)

The quotation contains a knowledge system as part of the cultural elements, as it discusses the local people's action to promote a safe way of fishing by avoiding the use of electricity, poison and bombs, in addition to utilizing standardized fishing tools. 
"Meningkatkan kesadaran masyarakat bahwa daerah Pancer sangat layak untuk dijadikan tempat wisata domestik maupun mancanegara"

'Improving the public awareness that Pancer is feasible to be developed as a domestic and international tourism destination' (page 3)

The quotation contains a knowledge system as part of the cultural elements, as it discusses the local people's behavior to preserve the coastal area through cooperative attempts.

\subsection{Social Organization Elements}

The social organization elements consist of the integrated social members within the society. It includes the lineage, association and community, state system, and united life system. The following data are the evidence of the existing social organization elements in the folktale. "Berawal dari berdirinya KUB (Kelompok Usaha Bersama) yang dibina oleh Dinas Kelautan bernama Paguyuban Srono Jolo atau Sarana Jala”

'It was started by the establishment of a Joint Business Group fostered by the Maritime Affairs Agency called Paguyuban Srono Jolo or Paguyuban Sarana Jala' (page 2)

The quotation contains a social organization system as part of the cultural elements, as it discusses a particular community established by the local people to help them in holding the communal communication for commonweal.

"Kegiatan ini juga merangkul komunitas anggota selancar PSC (Pacitan Surfing Club) untuk bekerja sama dalam menjalankan kegiatan tersebut. Selain itu ada juga POKMASWAS (Kelompok Masyarakat Pengawas)”,

'The activity also embraces PSC (Pacitan Surfing Club) and POKMASWAS (Kelompok Masyarakat Pengawas) through a collaboration of the program' (page 2)

The quotation contains a social organization system as part of the cultural elements, as it discusses the existing community that established a mutual cooperation to hold the series of activities related to Ngambu Pancer.

"Kemudian terbentuk juga POKDARWIS (Kelompok Sadar Wisata) yang masih diketuai juga oleh Bapak Sunyoto Karyawan"

'We also established POKDARWIS (Kelompok Sadar Wisata) chaired by Mr. Sunyoto Karyawan' (page 3)

The quotation contains a social organization system as part of the cultural elements, as it discusses the existing community that reflected the local people's attempt in managing and maintenance the coastal natural view for the sake of tourism attraction.

\subsection{Religious System Elements}

The religious system is comprehended as the integrated system of faith and religious practices related to the holiness and unreasonable concepts. The system includes faith, values and way of life, religious communication, and religious ceremony. The following data are the evidence of the existing religious elements in the folktale. 
"Di kawasan suci tersebut pada zaman nenek moyang yang sering digunakan untuk pertapaan adalah Watu Kelir, Watu Mejo, dan Watu Goa Bale"

'At the ancestral era, the holy regions that were used as the meditation points included Watu Kelir, Watu Mejo, and Watu Goa Bale' (page 1)

The quotation contains a religious system as part of the cultural elements, as it discusses sacred places that have been utilized as the meditation area since the ancestral time up to now.

“Kemudian memanjatkan do'a kepada Sang Maha Pencipta yakni Tuhan Yang Maha Esa untuk meminta keselamatan, kesehjateraan dan rezeki yang melimpah”

'Then prayed toward The One and Almighty God as The Creator of the universe, to supplicate for safety, prosperity, and abundance of sustenance' (page 1)

The quotation contains a religious system as part of the cultural elements, as it expresses the gratitude of the coastal communities to God for the abundance of blessing.

"Kegiatan ini dimulai dari tahun 2015 dan dikemas secara menarik dengan diadakannya upacara adat Ngambu Pancer"

'The activity was started in 2015 and interestingly socialized as Ngambu Pancer traditional ceremony' (page 3)

The quotation contains a religious system as part of the cultural elements, as it discusses the traditional ceremony that reflects the local people's cultural and spiritual manifestation.

Based on the findings, the researcher summed up a resolution that Ngambu Pancer folktale from Pacitan Regency contains a number of cultural elements, including knowledge system, social organization, and religious system. The cultural elements reflect the local people's sociocultural life as part of their ancestral heritage that gives positive social and spiritual impacts. The findings were relevant with [17] that explained ethnography as the comprehension to the cultural elements. It featured the perspective focus of Makassar folktale related to myth, religion, language, and tradition. Meanwhile, the current study focused on the Pacitan folktale by referring to three perspectives, including knowledge system, social organization, and religious system. Other relevant study was from [18] that discussed the local belief to the existence of Kanjeng Ratu Nyi Roro Kidul as the Queen of Southern Sea in Sukabumi Regency. The belief is firmly adhered by the local people to protect themselves from disasters [19].

\section{CONCLUSION}

The study concludes that Ngambu Pancer folktale from Pacitan Regency belongs to the phenomenal historical track. It is renowned with its mystical aspects believed by the local society due to the oral dissemination. The folktale describes the cultural elements, including () knowledge system, (2) social organization, and (3) religious system. The knowledge system includes the comprehension of the nature, flora and fauna, time, space and numbers, human character and behavior, and human body. The social organization includes the lineage, association and community, state system, and united life system. Meanwhile, the religious 
system consists of faith, values and way of life, religious communication, and religious ceremony.

\section{REFERENCES}

[1] L. E. Pradita, K. Sadhono, and M. Rohmadi, "Traditional Expressions As a Reflection of Cirebon Socio-Cultural Life : A Case Study of Petatah-petitih Sunan Gunung Jati."

[2] I. Suwartini and F. Merawati, "The Coastal Culture of the People of Indonesia and Malaysia the Folklore Malin Kundang and Si Tanggang," in Proceedings of the 2nd Workshop on Language, Literature and Society for Education, 2019.

[3] A. Rahadini, K. Wijayanti, and F. Kurwidaria, "Jamasan Jimat Tradition in Dawuhan Village as a Cultural Heritage based on Banyumas Society," in Proceedings of the 2nd Workshop on Language, Literature and Society for Education, 2019.

[4] H. Hilmiyatun, S. Suwandi, H. Waluyo, and N. Wardani, "The Cultural Representation of Lelakaq Sasak Lombok In The Folklore of Dewi Rengganis (Analysis of Form, Function and Meaning)," in Proceedings of the 2nd Workshop on Language, Literature and Society for Education, 2019.

[5] L. Feize, D. A. Longoria, and A. Fernandez, "Employing Mexican American Folklore as an Educational Tool to Teach Cultural Competence," 2019.

[6] A. R. Puspita, "DALAM SAJEN SLAMETAN NJANGKAR ( KAJIAN ETNOLINGUISTIK ) THE REFLECTIONS OF THE PEOPLE OF PRIGI COASTAL IN SAJEN SLAMETAN NJANGKAR,” vol. 20, no. 2, pp. 261-272, 2018.

[7] A. K. Deb, "“ Surrender to nature' : Worldviews and rituals of the small-scale coastal fi shers of Bangladesh," Mar. Policy, no. October 2017, pp. 0-1, 2018.

[8] W. Abdullah and E. Subroto, "Local Wisdom of Fisherman in Language and Livelihood Tradition in South Coastal of Kebumen Central Java Indonesia . ( Study of Etnolinguistik ) 1," vol. 280, no. Basa, pp. 136-142, 2018.

[9] A. S. Tuyakbaevaa, "Traditional Ceremonies and Rituals of Kazakh People as the Reflection of the Spiritual Culture in the Kazakh Cinematograph," Int. J. Environ. Sci. Educ., vol. 11, no. 12, pp. 5182-5197, 2016.

[10] N. Heo and H. Lee, "Sea deity beliefs of the Kuroshio oceanic cultural sphere : maritime traditions and cultural interaction among Jeju Island, Zhoushan Archipelago, and the Ryukyu Islands," vol. 13, no. 1, pp. 171-184.

[11] H. G. Budiman, "THE MEANING AND CULTURAL VALUES OF TAPIS INUH," J. Patanjala, vol. 05, no. 03, pp. 519-534, 2013.

[12] N. K. Ratna, Antropologi Sastra: Peranan Unsur-Unsur Kebudayaan dalam Proses Kreatif. Yogyakarta: PUSTAKA PELAJAR, 2011.

[13] Koentjaraningrat, Pengantar Ilmu Antropologi. 2009.

[14] A. R. Radcliffe-Brown, "The Comparative Method in Social Anthropology," J. R. Anthropol. Inst. Gt. Britain Irel., 2006.

[15] H. F. Wolcott, Ethnography Lessons: A Primer. Walnut Creek, CA: Left Coast Press, 2010 .

[16] J. W. Creswell, Qualitative Inquiry \& Research Design: Choosing Among Five Approaches. 2013.

[17] S. Djirong, "Kajian Antropologi Sastra Cerita Rakyat Datumuseng dan Maipa Deapati," Sawerigading, vol. 20, no. 2, pp. 215-226, 2014.

[18] D. Muslim, E. Haerani, Z. Zakaria, and R. I. Sophian, "DISASTER CULTURE FOR THE SCHOOL IN CISOLOK OF SUKABUMI REGENCY , WEST JAVA , INDONESIA," no. July 2006. 
[19] B.W. Setyawan and K. Saddhono, "Eret traditional ceremony as representation of spirit of mutual cooperation among coastal communities". Adv. Sci. Let. vol. 23 no.10, pp 99919992, 2017 